\title{
脺臓内分泌細胞の分化とホルモン分泌を調節する新規分子の発見とその作用機序の解明
}

\author{
岡 孝己, ${ }^{*}, a$ 大 谷 政 博, ${ }^{b}$ 鈴木順一朗 $c$
}

\section{Identification of Novel Molecules Regulating Differentiation and Hormone Secretion and Clarification of Their Functional Mechanisms in Pancreatic Endocrine Cells}

\author{
Takami OKA, ${ }^{*, a}$ Masahiro OHTANI, ${ }^{b}$ and Jun-ichiro SUZUKI ${ }^{c}$ \\ ${ }^{a}$ Research Institute of Pharmaceutical Sciences, Musashino University, 1-1-20 Shinmachi, Nishi-Tokyo, Tokyo 202-8585, \\ Japan, ${ }^{b}$ Department of Pharmacology, Osaka Dental University, 8-1 Kuzuhahanazono-cho, Hirakata, Osaka \\ 573-1121, Japan, and 'Signaling Molecules Research Group, Neuroscience Research Institute, AIST \\ Tsukuba Central 6, 1-1-1 Umezono, Tsukuba, Ibaraki, 305-8568, Japan
}

(Received November 6, 2009)

\begin{abstract}
In order to find novel bioactive molecules regulating differentiation and hormone secretion of pancreatic endocrine cells, the effects of various substances including purinergic receptor agonists and inhibitors of polyamine biosynthesis were examined in pancreatic islets and several pancreatic cell lines. The nicotinic alpha3beta4 receptor was found to be present and capable of increasing cytoplasmic $\mathrm{Ca}^{2+}$ concentration $\left(\left[\mathrm{Ca}^{2+}\right]_{\mathrm{i}}\right)$ and insulin secretion in mouse pancreatic Beta-TC6 cells. Activation of both nicotinic and muscarinic $\mathrm{M}_{3} / \mathrm{M}_{4}$ receptors resulted in reduction of insulin release when compared with stimulation of muscarinic receptor alone in Beta-TC6 cells. In mouse islets, purinergic $\mathrm{P}_{2} \mathrm{Y}_{1}$ and $\mathrm{P} \mathrm{Y}_{6}$ receptors, which are coupled to Gq proteins, were expressed and appeared to regulate insulin secretion through $\mathrm{Ca}^{2+}$ mobilization from intracellular stores. Similar results were observed in Beta-TC6 cells. Spermidine, one of polyamines, was found to modulate insulin synthesis and $\left[\mathrm{Ca}^{2+}\right]_{\mathrm{i}}$ in Beta-TC6 cells by use of a specific spermidine synthesis inhibitor, trans-4-methylcyclohexylamine (MCHA). Antizyme, which binds to ornithine decarboxylase (ODC) and thereby reduces the cellular polyamine level, was found to be necessary for conversion of ASPC-1 cells, a pancreatic ductal tumor cell line, into alpha-cells forming the islet-like structure and expressing glucagon gene. These findings help advance our understanding of the complex mechanisms involved in the regulation of pancreatic endocrine cell function and develop new therapeutic agents in diabetes mellitus.
\end{abstract}

Key words_— - pancreas; receptor; calcium; polyamine; insulin; glucagon

\section{1. はじめに}

加齢に伴って発症する 2 型糖尿病の主な原因とし て, 膵臓における $\beta$ 細胞数の減少やインスリン分 泌能の低下, 筋や脂肪組織におけるインスリン効力 の低下などが挙げられる。2 型糖尿病は生活習慣病 であり，食生活の豊かさや運動不足による肥満も遺 伝的要因とともに発症の危険因子となる。厚生労働 省の平成 19 年度の調査によると, 糖尿病患者数は

武蔵野大学薬学研究所（干202-8585 東京都西東京市新 町 1-1-20)

現所属： $a$ 湧永製薬株式会社中央研究所（干739-1195 広島県安芸高田市甲田町下甲立 1624 番地), ${ }^{b}$ 大阪歯科 大学薬理学講座（干573-1121 大阪府枚方市楠葉花園町 8-1), c独立行政法人産業技術総合研究所脳神経情報研 究部門シグナル分子研究グループ（テ305-8568 茨城県 つくば市梅園 1-1-1)

*e-mail: oka_tm@wakunaga.co.jp

本総説は, 平成 20 年度退職にあたり在職中の業績を中 心に記述されたものである。
予備軍を含めると約 2200 万人に達していると推定 され，欧米だけではなく日本でも近年増加の一途を たどっている．したがって現在，2 型糖尿病の有効 な新しい治療法及び治療薬の早期の開発が望まれて いる.

筆者（岡）は, 米国立衛生研究所（National Institute of Health, NIH）で乳腺細胞の増殖・分化を 制御するホルモンなどの作用機構の解明を目指して 約 30 年間にわたり研究を行ってきた。その後, 2004 年に武蔵野大学薬学部遺伝子学研究室の教授 として赴任した。その際，NIH 在籍当時から興味 を持っていた糖尿病の新規の治療法又は治療薬の開 発を目指した研究に取り組むこととし，NIH 博士 研究員をしていた大谷政博博士とともに研究グルー プを形成し，グルカゴンやインスリンなど血糖值の 調節に必要不可欠なホルモンを生合成・分泌する $\alpha$ や $\beta$ 細胞などからなる膵臓ランゲルハンス島（膵 
島）や， $\beta$ 細胞由来の数種の細胞株を用いて細胞レ ベルでの基礎的研究を開始した．大谷博士がムスカ リン性及びニコチン性アセチルコリンレセプターに 結合するコリン作動薬の研究に従事していたことか ら，最初に様々なアゴニストの薬理作用を網羅的に 調べた。その結果，二コチンが $\beta$ 細胞株からのイ ンスリン分泌を促進することなど興味ある知見を得 ることができた。その後も，ATPなどのヌクレオ チドが結合するプリン作動性レセプターの新規のサ ブタイプや，細胞の増殖や分化に必須の働きを持つ 塩基性ポリカチオンであるポリアミン，またその生 合成を調節するアンチザイムなどが， $\beta$ 細胞からの インスリン分泌や $\alpha$ 細胞の分化の制御に係わって いることを明らかにすることができた。本稿では， 武蔵野大学在籍時に行った研究成果を中心にその研 究背景と概略を述べたい.

\section{2. $\beta$ TC6 細胞におけるニコチン性アセチルコリ} ンレセプターによるインスリン分泌の調節1)

膵島 $\beta$ 細胞は，血中グルコース濃度（血糖值） の上昇に応答してペプチドホルモンであるインスリ ンを生合成し，血中に分泌する，分泌されたインス リンは，標的器官である筋組織や肝臓等に作用し， 筋肉細胞内へのグルコースの取り込みや代謝の促 進，また肝細胞でのグリコーゲン合成の促進や糖新 生の抑制などを引き起こすことによって血糖值を低 下させる． $\beta$ 細胞からのインスリン分泌は，血中グ ルコース濃度の増加により上昇し，アセチルコリ ン，ノルアドレナリンやアミノ酸などの様々な神経 伝達・生理活性物質によって調節されていることが 知られている. ${ }^{2)}$ 膵島に神経分布している副交感神 経終末から放出されるアセチルコリンは, 膵島 $\beta$ 細胞膜上に存在するムスカリン性アセチルコリンレ セプターの $\mathrm{Gq}$ タンパク連結型 $\mathrm{M}_{3}$ サブタイプに結 合してインスリン分泌を促進することが，単離した 膵島や $\beta$ 細胞株及び $\mathrm{M}_{3}$ ノックアウトマウスを用い

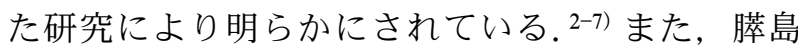
でのホルモン分泌の調節においては, 細胞内カルシ ウムイオン濃度 $\left(\left[\mathrm{Ca}^{2+}\right]_{\mathrm{i}}\right)$ がグルコースや $\mathrm{M}_{3} レ$ セプター2,8)の刺激によって上昇する．以下に，こ れらの刺激によって $\beta$ 細胞の $\left[\mathrm{Ca}^{2+}\right]_{\mathrm{i}}$ が上昇する メカニズムについて述べる.

グルコース刺激では，血中のグルコース濃度が上 昇すると, グルコーストランスポーター 2 (GLUT2)

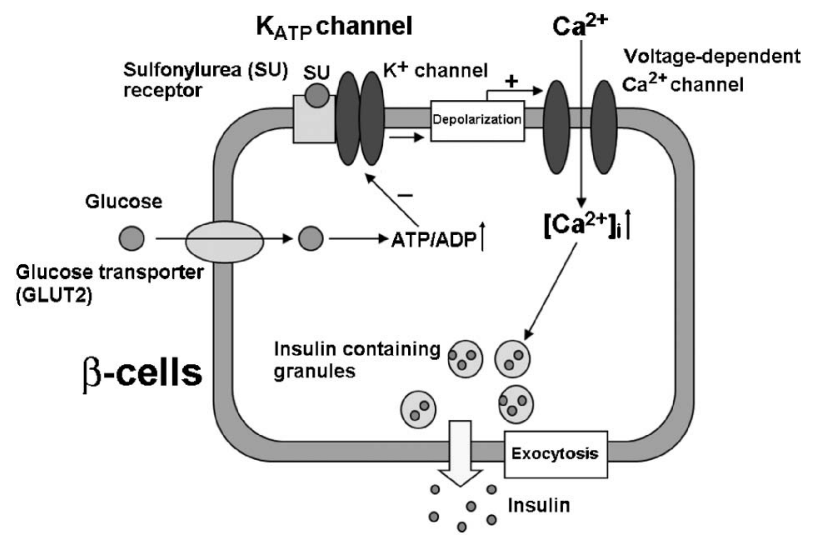

Fig. 1. Signaling Pathway Involved in Insulin Secretion Induced by Glucose in Pancreatic $\beta$-cells

The processes in which the increase in the ratio of ATP/ADP closes $\mathrm{K}_{\mathrm{ATP}}$ channels and the subsequent membrane depolarization opens voltagedependent $\mathrm{Ca}^{2+}$ channels are indicated by - and + , respectively. ADP: adenosine $5^{\prime}$-diphosphate. $\left[\mathrm{Ca}^{2+}\right]_{\mathrm{i}}$ : cytoplasmic $\mathrm{Ca}^{2+}$ concentration.

を介して $\beta$ 細胞内にグルコースが取り込まれ，代 謝されて ATP 産生が充進し，ATP/ADP 比が上昇 する（Fig. 1)。この比の上昇によって ATP 感受性 カリウムチャネルが閉口して細胞膜が脱分極し，続 いて電位感受性カルシウムチャネルが開き細胞内に $\mathrm{Ca}^{2+}$ が流入して $\left[\mathrm{Ca}^{2+}\right]_{\mathrm{i}}$ が上昇する。次に，この $\left[\mathrm{Ca}^{2+}\right]_{\mathrm{i}}$ 上昇が引き金となってインスリンを含む顆 粒が exocytosisによって細胞外へ放出される。一方, $\mathrm{M}_{3}$ レセプター刺激の場合は，まず，リガンドのレ セプターへの結合によって三量体 $\mathrm{G}$ タンパクから 解離した $\mathrm{Gq} \alpha$ サブユニットがホスホリパーゼ $\mathrm{C} \beta$ (PLC $\beta)$ を活性化する. 次に, 活性化された PLC $\beta$ の作用によって，ホスファチジルイノシトール 4,5二リン酸 $\left(\mathrm{PIP}_{2}\right)$ からセカンドメッセンジャーと して働くイノシトール $1,4,5$-三リン酸 $\left(\mathrm{IP}_{3}\right)$ が産 生される。次に, $\mathrm{IP}_{3}$ が細胞内の $\mathrm{Ca}^{2+}$ 貯蔵部位で

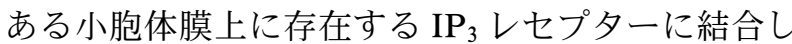
て, 細胞質へ $\mathrm{Ca}^{2+}$ が動員されることによって $\left[\mathrm{Ca}^{2+}\right]_{\mathrm{i}}$ が上昇する。このように， $\beta$ 細胞からのイ ンスリン分泌において, $\left[\mathrm{Ca}^{2+}\right]_{\mathrm{i}}$ の上昇が重要な要 因の 1 つとなつているので，これをホルモン分泌に 影響を及ぼす物質のスクリーニングの指標として用 いることとした。また，膵島は 1 個体のマウスやラ ットからは微量しか単離できず，さらに培地中で増 殖せず，かつ長期間の維持も難しいので， $\beta$ 細胞株 の一種で市販されているマウス由来の $\beta \mathrm{TC} 6$ 細胞を 用いることとした。この実験系で既知の様々なリガ 
ンドの $\left[\mathrm{Ca}^{2+}\right]_{\mathrm{i}}$ に対する薬理作用を調べたところ， ムスカリン性アゴニストだけではなく，ニコチン性 レセプターのアゴニストであるニコチンが, $10 \mu \mathrm{M}$ 以上で濃度依存的に $\left[\mathrm{Ca}^{2+}\right]_{\mathrm{i}}$ を上昇させる作用を 示すことを見い出した。これは，膵臓 $\beta$ 細胞に二 コチン性レセプターが存在し，機能していることを 示唆する最初の知見であり, 興味深いものであつ た。またニコチン性レセプターに最も高い親和性 を持つカエル皮膚由来の epibatidine ${ }^{9)}$ の $\mathrm{EC}_{50}$ 值は $20 \mathrm{nM}$ であり，これはニコチンの值よりも約 1000 倍低いものであった．さらに，ニコチンが $\beta \mathrm{TC6}$ 細 胞の細胞膜電位を $1 \mu \mathrm{M}$ 以上で脱分極させることも わかった。次に，アンタゴニストや阻害剤を用いて ニコチンの作用機構を調べてみると，ニコチンの $\left[\mathrm{Ca}^{2+}\right]_{\mathrm{i}}$ 上昇作用は，ムスカリン性レセプターの非 特異的アンタゴニストであるアトロピンやスコポラ ミンによってはほとんど阻害を受けなかったが [Fig. 2(A)]， ニコチン性レセプターの非特異的ア ンタゴニストであるメカミルアミンによって完全に 抑制された [Fig. 2(B)]。これらの結果から，ニコ チンがムスカリン性ではなく，ニコチン性レセプ ターを介して $\left[\mathrm{Ca}^{2+}\right]_{\mathrm{i}}$ の上昇を引き起こしている ことが示唆された.

ニコチン性レセプターは, $\alpha, \beta, \delta, \varepsilon$ (成人) そし て $\gamma$ （胎児）の 5 つのサブユニットの組み合わせか らなり，神経型と筋肉型に大別される. ${ }^{10)}$ 神経型は,

9 種の $\alpha(\alpha 2-10)$ と 3 種の $\beta(\beta 2-4)$ サブユニット から構成される五量体であると考えられており, ${ }^{10}$ これらの組み合わせの多様性から，様々なユニット 構成を持つレセプターが同一又は複数の細胞や組織 にまたがって存在していることが予想される。した がって，レセプターサブタイプのサブユニットの組
み合わせを特定することは，特異的なアゴニストや アンタゴニストがこれまで十分に開発されていない こととも相まって非常に困難であった，そこで，特 定のサブタイプしか発現していない細胞や，決まっ た種類の組み合わせからなるレセプターのみを発現 させた chinese hamster ovary（CHO）細胞などを用 いて，リガンドの結合様式からサブユニットの組み 合わせを類推する試みがなされている。われわれ は，ニコチン性レセプターの種々のアゴニストの作 用機序と，他の研究者の報告11,12) 基にわれわれの 得たデー夕を解析した結果， $\beta \mathrm{TC6}$ 細胞に発現して いるニコチン性レセプターは $\alpha 3 \beta 4$ タイプであるこ とを示唆する知見を得た。ささに, reverse transcription-polymerase chain reaction (RT-PCR) 法に よって $\beta \mathrm{TC} 6$ 細胞で $\alpha 3$ と $\beta 4$ のサブユニットの mRNA が存在していることを確認し， $\alpha 3 \beta 4$ タイプ のレセプターが発現していることを裏付ける証拠を 得ることができた。また，ニコチン性レセプターを 刺激することによって，グルコースによって引き起 こされるインスリン分泌がどのように影響されるか を調べたところ，ニコチン濃度の増加に依存してイ ンスリン分泌が促進されることが明らかとなった。

これらの研究結果により，ニコチン性レセプターが $\beta$ 細胞におけるインスリン分泌の調節に係わってい る可能性が示唆された.

3. $\beta \mathrm{TC6}$ 細胞におけるインスリン分泌に関する ニコチン性レセプターとムスカリン性レセプターと の相互作用 ${ }^{13)}$

上で述べたように，ムスカリン性レセプターが正 常 $\beta$ 細胞で機能していることはよく知られていた ので，われわれは $\beta \mathrm{TC} 6$ 細胞におけるその発現を調 ベた，RT-PCR を行ったところ， $\mathrm{M}_{3}$ とともに $\mathrm{M}_{4}$
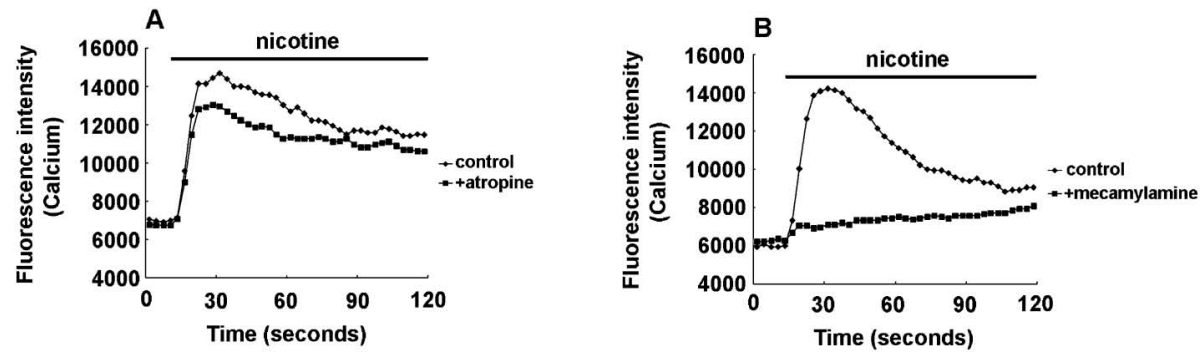

Fig. 2. Effect of Muscarinic and Nicotinic Antagonists on the Rise in $\left[\mathrm{Ca}^{2+}\right]_{\mathrm{i}}$ Induced by Nicotine in Beta-TC6 Cells

The temporal $\left[\mathrm{Ca}^{2+}\right]_{\mathrm{i}}$ response to nicotine $(100 \mu \mathrm{M})$ was measured in Hanks/HEPES buffer ( $\left.\mathrm{pH} 7.4\right)$ for $120 \mathrm{~s}$ in the absence (control) or presence of (A) a nonspecific muscarinic antagonist, atropine $(10 \mu \mathrm{M})$ or $(B)$ a nonspecific nicotinic antagonist, mecamylamine $(10 \mu \mathrm{M})$. Each reagent was present during the period indicated by bar. 
サブタイプも発現していることが明らかとなった。 これらの結果から， $\beta \mathrm{TC} 6$ 細胞にニコチン性とムス カリン性の両方のレセプターが発現していることが わかり，この細胞株は $\beta$ 細胞におけるインスリン 放出過程における両レセプターの相互作用を調べる のに適した細胞モデルの 1 つであると考えられた. そこで，ムスカリン性レセプターに特異的なアゴニ ストである oxotremorine M，ニコチン性レセプ ターのアゴニストであるニコチン，両レセプターに 結合し得るアセチルコリンのアナログであるカルバ コールを用いて， $\left[\mathrm{Ca}^{2+}\right]_{\mathrm{i}}$ とインスリン分泌に及ぼ す作用を調べた。 $\left[\mathrm{Ca}^{2+}\right]_{\mathrm{i}}$ の上昇反応についてはカ ルバコールが最も強く，ついで oxotremorine $\mathrm{M}$, ニコチンの順であった. また, カルバコールの効果 は，アトロピンとメカミルアミンの両方によって阻 害されたが [Fig. 3(A)]， oxotremorine M の効果 はメカミルアミンによっては阻害されなかった [Fig. 3(B) ]。この阻害様式から，カルバコール は，ムスカリンとニコチン性の両レセプターを刺激 することにより $\left[\mathrm{Ca}^{2+}\right]_{\mathrm{i}}$ の上昇作用を引き起こす ことが示唆された。この作用はニコチンあるいは oxotremorine $\mathrm{M}$ 単独での作用より若干強いもので あった。さらに，カルバコールと oxotremorine M の両方の効果が $\mathrm{M}_{3}$ 及び $\mathrm{M}_{4}$ レセプターの選択的ア ンタゴニストや，PLC，ホスホリパーゼ $\mathrm{A}_{2}$ $\left(\mathrm{PLA}_{2}\right)$ やプロテインキナーゼ C $(\mathrm{PKC})$ の各種阻 害剂によって抑制されたことから， $\mathrm{PLC} / \mathrm{IP}_{3}$ 経路 やアラキドン酸代謝経路などが $\mathrm{M}_{3}$ 又は $\mathrm{M}_{4}$ レセプ ター（あるいは両方のレセプター）刺激による $\left[\mathrm{Ca}^{2+}\right]_{\mathrm{i}}$ の上昇反応に関与している可能性が考えら れた。一方，ニコチンの場合と同様に，インスリン 分泌はカルバコール及び oxotremorine M の添加に
よって濃度依存的に増大したが，100 $\mu \mathrm{M}$ での分泌 量は, カルバコール刺激の方が oxotremorine $\mathrm{M}$ 単 独刺激に比べて少なかった。このことは，ムスカリ ン性レセプターを単独で刺激した場合よりも，二コ チン性及びムスカリン性の両レセプターを刺激した 場合の方がインスリン分泌量が減少することを示し ている，したがって，両レセプターの刺激により生 じる $\left[\mathrm{Ca}^{2+}\right]_{\mathrm{i}}$ 上昇後のシグナル伝達の過程で，な んらかの負 (negative) の相互作用が起きている可 能性が考えられた。これらの詳細なメカニズムは今 後調べていきたいと考えている.

上述したニコチンの効果が $\beta \mathrm{TC} 6$ 細胞だけに特有 なものかどうかを明らかにするために，他の動物種 の $\beta$ 細胞株や初代培養膵島を用いた実験を行っ た。その結果，ラット由来の RINm5F 細胞，八ム スター由来の HIT-T15 細胞そしてマウス膵島いず れにおいて，ニコチン及び数種のニコチン性アゴニ ストを作用させても $\left[\mathrm{Ca}^{2+}\right]_{\mathrm{i}}$ に全く影響はみられ なかった。 また，マウスの膵島から total RNA を 抽出して RT-PCR を行ったところ，ニコチン性レ セプターのいずれのサブユニットも検出されなかつ た。したがって現時点では，上で述べたニコチンの 作用は $\beta$ TC6 細胞に特有のものである考えられる. しかしながら，ラットやヒトから単離した膵島にお けるインスリン分泌がニコチン添加によって抑制さ れるという報告がなされていることから, 14) マウス 以外の動物の $\beta$ 細胞にニコチン性レセプターが存 在し，インスリン放出の調節に係わっている可能性 が考えられる。また一方， $\beta \mathrm{TC6}$ 細胞は，サルのが んウイルスの一種である SV40 ウイルスのラージ T 抗原遺伝子を導入することにより樹立された腫瘍 $\beta$ 細胞株（インスリノーマ）の一種であるので, ${ }^{15)}$ 正
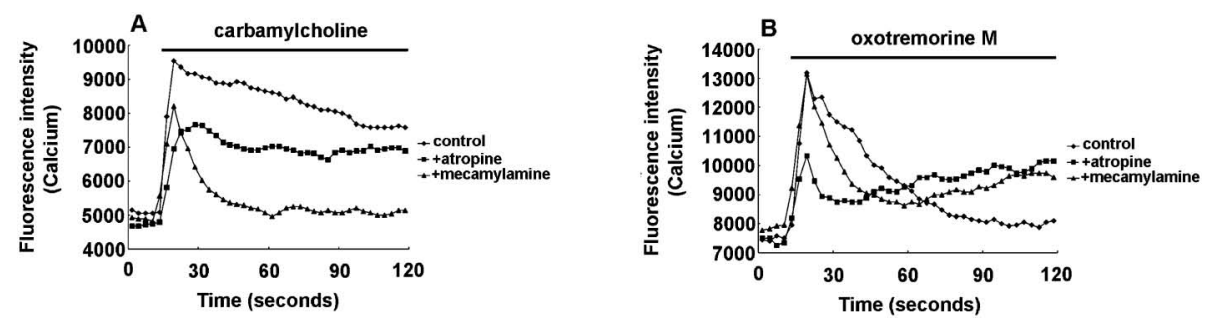

Fig. 3. Effect of Muscarinic and Nicotinic Antagonists on the Rise in $\left[\mathrm{Ca}^{2+}\right]_{\mathrm{i}}$ Induced by Carbamylcholine or Oxotremorine M in Beta-TC6 Cells

The temporal $\left[\mathrm{Ca}^{2+}\right]_{\mathrm{i}}$ response to carbamylcholine or oxotremorine $\mathrm{M}(100 \mu \mathrm{M})$ was measured in Hanks/HEPES buffer (pH 7.4) for $120 \mathrm{~s}$ in the absence (control) or presence of (A) a nonspecific muscarinic antagonist, atropine $(10 \mu \mathrm{M})$ or $($ B) a nonspecific nicotinic antagonist, mecamylamine $(10 \mu \mathrm{M})$. Each reagent was present during the period indicated by bar. 
常な $\beta$ 細胞が腫瘍化したことでニコチン性レセプ ターが発現し，インスリン分泌の調節に関与してい る可能性も考えられる.

\section{4. 膵島でのインスリン分泌におけるプリン作動} 性レセプターの役割16)

ATP はエネルギー通貨とも呼ばれ，すべての細 胞で生合成され，様々な代謝反応に用いられるエネ ルギー供給物質としてよく知られている。 しかし近 年，ATP やその関連ヌクレオチドが神経伝達物質 やホルモンとともに細胞外へ放出され， autocrine や paracirne 様式により細胞膜に存在するプリン作 動性（P2）レセプターに結合して，種々の生理作用 を発現することがわかってきた。 ${ }^{17)} \mathrm{P} 2$ レセプター は，イオンチャネル型の $\mathrm{P} 2 \mathrm{X} と \mathrm{G}$ タンパク連結型

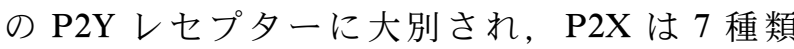
$\left(\mathrm{P} 2 \mathrm{X}_{1-7}\right), \mathrm{P} 2 \mathrm{Y}$ は 8 種類 $\left(\mathrm{P} 2 \mathrm{Y}_{1,2,4,6,11-14}\right)$ のサブ タイプに分けられる. ${ }^{18)} \mathrm{P} 2$ レセプターは，ほぼす べての動物細胞や組織に存在しており，神経系，免 疫系や循環器系などでその働きが研究されて多くの 興味ある知見が得られている. ${ }^{19,20)}$ しかし，本研究 を開始した当時は，膵臓でのインスリン分泌に伴い 顆粒中の ATP が細胞外に放出されることは知られ ていたが, ${ }^{21)} \beta$ 細胞における $\mathrm{P} 2$ レセプターサブタ イプに関する知見は少なく，その機能と生理的意義 はわかっていなかった，そこでわれわれは，まず， マウスから単離した膵島を用いて, 数種の P2レセ プターのアゴニストの $\left[\mathrm{Ca}^{2+}\right]_{\mathrm{i}}$ とインスリン分泌に 関する作用を調べてみた。その結果，ATP及び $\mathrm{P}^{2} \mathrm{Y}_{1,12,13}$ レセプターの内因性アゴニストである ADP やその合成アゴニストである 2-methylthioADP (2-MeSADP)，そして $\mathrm{P}_{2} \mathrm{Y}_{6} レ$ レプターの選択的ア ゴニストである uridine 5'-diphosphate (UDP) 等 が通常の血中グルコース濃度（5.5 mM）下で $\left[\mathrm{Ca}^{2+}\right]_{\mathrm{i}}$ を一過性に上昇させることが明らかとなつ た。しかし一方， $\mathrm{P}^{2} \mathrm{Y}_{2,4}$ レセプターに親和性の高 い uridine $5^{\prime}$-triphosphate (UTP) やP2Xレセプ ターのアゴニストである $\alpha, \beta$-methyleneATP は同様 の効果を示さなかった。これらの実験結果から, $\mathrm{P} 2 \mathrm{Y}_{1,6,12,13}$ レセプターが膵島で $\left[\mathrm{Ca}^{2+}\right]_{\mathrm{i}}$ の上昇に 係わっている可能性が示唆された。

細胞外の ATP は, 細胞膜や血中に存在するヌク レオチド分解酵素によって, ADP や adenosine 5'monophosphate (AMP) を経て, 最終的にアデノ
シンに急速に分解されることが知られている. ${ }^{17,22)}$ またアデノシンについても細胞膜上にアデノシンレ セプター $\left(\mathrm{A}_{1}, \mathrm{~A}_{2 \mathrm{~A}}, \mathrm{~A}_{2 \mathrm{~B}}, \mathrm{~A}_{3}\right)$ が存在するので, ${ }^{20)}$ 添 加した ATP $\mathrm{ADP}$ がアデノシンに変換されて, $\left[\mathrm{Ca}^{2+}\right]_{\mathrm{i}}$ の上昇を引き起こしている可能性が考えら れた。そこで，アデノシンレセプターの非特異的な 合成アゴニストである $5^{\prime}-N$-ethylcarboxamide adenosine（NECA）を用いて実験を行ったところ, $\left[\mathrm{Ca}^{2+}\right]_{\mathrm{i}}$ に対しては全く効果を示さなかったので, 上述の可能性は低いと考えられた。次に RT-PCR 解析を行った結果， $\mathrm{P}_{2} \mathrm{Y}_{1}$ と $\mathrm{P}_{2} \mathrm{Y}_{6} レ$ レプターの mRNA の膵島での発現が明らかとなったので，こ れら 2 種のレセプターが膵島で機能していることが 考えられた。 また，他の組織や細胞において，これ らレセプターが Gq タンパクと連結していることが 報告されていたので, ${ }^{20,23)}$ われわれは PLC/ $\mathrm{IP}_{3}$ 経 路の阻害剂を用いた実験を行い，これらレセプター の刺激に伴ってこの経路が活性化していることを示 唆するデー夕を得た。以上の結果から，通常グル コース濃度 $(5.5 \mathrm{mM})$ の存在下で，マウス膵島中 の $\mathrm{P}_{2} \mathrm{Y}_{1}$ 又は $\mathrm{P}_{2} \mathrm{Y}_{6}$ レセプターが刺激されると PLC $/ \mathrm{IP}_{3}$ 経路が活性化されて，次に小胞体から細胞質 への $\mathrm{Ca}^{2+}$ の流出が促進されることにより $\left[\mathrm{Ca}^{2+}\right]_{\mathrm{i}}$ が上昇することが明らかとなった（Fig. 4)。また， インスリン分泌について調べた結果, 通常濃度のグ ルコース存在下では両レセプターの刺激による分泌 量の上昇はごく限られたものであり，一方高濃度グ ルコース $(16.7 \mathrm{mM})$ 存在下では，逆にインスリン 分泌が抑制された。これらの結果は，ラット24-27)や ヒト ${ }^{28)}$ の膵島では P2 レセプター刺激によってイン スリン分泌が促進される現象とは異なったものであ った．現在のところ動物種によってなぜこのような 違いがみられるかの原因は明らかではない。また $\beta \mathrm{TC} 6$ 細胞を用いて同様の実験を行ったところ，マ ウス膵島での結果とほぼ一致した結果が得られた.

したがって，ニコチンの作用とは異なり，P2レセ プターに対する応答に関して $\beta \mathrm{TC} 6$ 細胞は正常なマ ウス $\beta$ 細胞の性質を保持していることが明らかと なった，なお，膵島での $\mathrm{P}_{2} \mathrm{Y}_{1}$ レセプターの存在に ついてはこれまでにいくつかの報告がなされていた が, ${ }^{29,30)} \mathrm{P} 2 \mathrm{Y}_{6}$ レセプターについては全くなく, 新 規の機能性レセプターであると考えられた。 さらに ほぼ同じ時期に，Parandeh らのグループが $\mathrm{P}_{2} \mathrm{Y}_{6}$ 


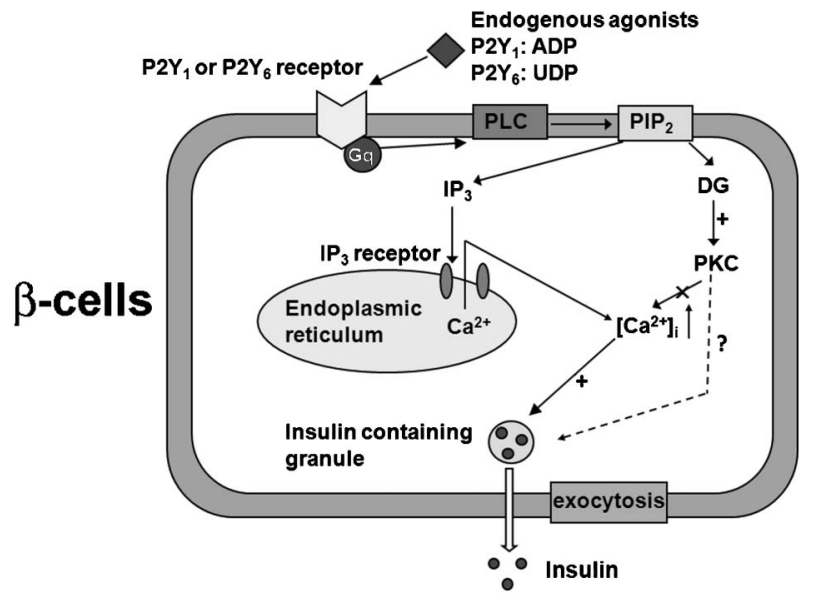

Fig. 4. Signaling Pathway Involved in Insulin Secretion through P2Y Receptor Activation in Mouse Pancreatic Islet $\beta$-cells

It is proposed that $\mathrm{P} 2 \mathrm{Y}_{1}$ or $\mathrm{P}_{2} \mathrm{Y}_{6}$ receptor activation elicits insulin secretion via $\mathrm{Ca}^{2+}$ mobilization in the presence of $5.5 \mathrm{~mm}$ glucose. The processes in which the rise in $\left[\mathrm{Ca}^{2+}\right]_{\mathrm{i}}$ triggers exocytosis of insulin containing granules and diacylglycerol (DG) activates protein kinase $\mathrm{C}$ (PKC), which does not influence $\left[\mathrm{Ca}^{2+}\right]_{\mathrm{i}}$ (indicated by $\times$ ), are indicated by + . UDP: uridine $5^{\prime}$ diphosphate. Gq: Gq subclass of GTP-binding protein $\alpha$ subunit. PLC: phospholipase $\mathrm{C}$. $\mathrm{IP}_{3}$ : inositol-1,4,5-triphosphate. $\mathrm{PIP}_{2}$ : phosphatidylinositol-4,5-bisphosphate.

レセプターのアゴニストが nM レベルでマウスの膵 島のインスリン分泌を促進することを報告したこと

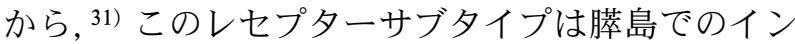
スリン分泌の調節に関与している可能性が考えられ る.

\section{5. 通常 $\boldsymbol{\beta}$ 細胞のモデル細胞としての $\beta$ TC6 細胞} の有用性と発現レセプターの特性の比較

正常 $\beta$ 細胞のモデル系細胞として，非市販のマ ウス由来の MIN6 細胞とラット由来の INS-1 細胞 がこれまで頻繁に使われてきた。この理由の 1 つと して，これらの細胞は市販の培養細胞（RINm5F や HIT-T15 細胞なども含む）に比べてグルコース に応答して起こるインスリン分泌反応が正常 $\beta$ 細 胞の特性に近いことが挙げられる。つまり，細胞外 のグルコース濃度を $5.5 \mathrm{~mm}$ から $20 \mathrm{~mm}$ に上げると 分泌量が大幅に増大する。年)一方, $\beta \mathrm{TC} 6$ 細胞で は，グルコース濃度を $0 \mathrm{~mm}$ から $1.3 \mathrm{~mm}$ に上げる とインスリン分泌が急激に促進され， $5.5 \mathrm{~mm}$ で最

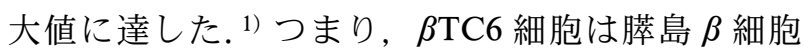
に比べて，グルコース応答の閾值濃度が低いことが わかつた。 また，膵島における $\left[\mathrm{Ca}^{2+}\right]_{\mathrm{i}}$ はグルコー 又濃度の増加に応答して上昇するが，その反応は二 相性である。第一相では一過性のピークがみられ，

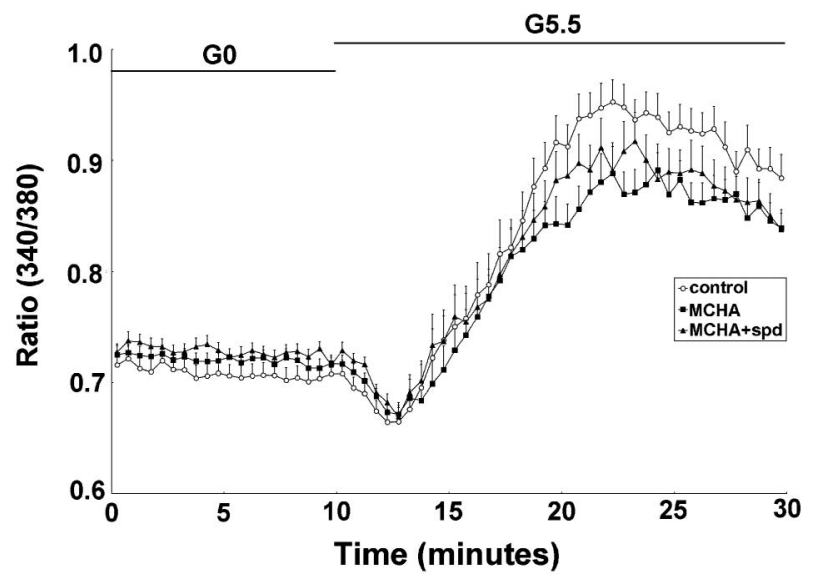

Fig. 5. Effect of Spermidine Synthesis Inhibitor MCHA on $\left[\mathrm{Ca}^{2+}\right]_{\mathrm{i}}$ in Beta-TC6 Cells

The cells were untreated (control) or treated with MCHA $(250 \mu \mathrm{M})$ alone or both MCHA and spermidine $(25 \mu \mathrm{M})$ for 3 days. The change in $\left[\mathrm{Ca}^{2+}\right]_{i}$ was monitored for $30 \mathrm{~min}$ using excitation at 340 and $380 \mathrm{~nm}$ and emission at $510 \mathrm{~nm}$ wavelengths after cells were loaded with a $\mathrm{Ca}^{2+}$ indicator, fura-2 acetoxymethyl ester $(1 \mu \mathrm{M})$ in Krebs/HEPES buffer $(\mathrm{pH}$ 7.4) and then incubated for $10 \mathrm{~min}$ in the absence of glucose $(0 \mathrm{~mm}, \mathrm{G} 0)$. Cells were then incubated in the buffer containing $5.5 \mathrm{~mm}$ glucose (G5.5) for $20 \mathrm{~min}$ as indicated by bar. Each value of the ratio $(340 / 380 \mathrm{~nm})$ measured at every 30 $\mathrm{s}$ represents the mean \pm S.E.M. $(n=40)$. The figure was quoted from our recent publication $^{34)}$ and presented as an altered version.

これに引き続いてベースラインより高い $\left[\mathrm{Ca}^{2+}\right]_{\mathrm{i}}$ 值で上下に変動して持続するオシレーションパター ンが観察される. ${ }^{8)}$ 一方 $\beta \mathrm{TC} 6$ 細胞では，第一相の ピークは明確でないが持続的な $\left[\mathrm{Ca}^{2+}\right]_{\mathrm{i}}$ の上昇が 観察され, 膵島と類似したグルコース応答がみられ た (Fig. 5)。このように, $\beta \mathrm{TC6}$ 細胞は膵島 $\beta$ 細胞 と比較して，インスリン分泌及び $\left[\mathrm{Ca}^{2+}\right]_{\mathrm{i}}$ の上昇 反応に関してはいくつか異なる性質を有するが，グ ルコース濃度の上昇に応答して $\left[\mathrm{Ca}^{2+}\right]_{\mathrm{i}}$ が持続的 に上昇し, インスリン分泌が促進されるという点に 関しては，正常 $\beta$ 細胞と似た特性を保持している ことが明らかとなった。

上で述べたように， $\beta \mathrm{TC} 6$ 細胞ではニコチン性レ セプター, ムスカリン性レセプター及びプリン作動 性（P2）レセプターが発現し, $\left[\mathrm{Ca}^{2+}\right]_{\mathrm{i}}$ やインスリ ン分泌の調節に関与していることが明らかとなつ た. 一方, 膵島と比較するといくつかの相違点が判 明し, 中でも最も大きな違いはニコチン性レセプ ターの遺伝子発現の有無である.これ以外のレセプ ターは膵島にも発現しており, リガンドのレセプ ターへの結合からインスリン分泌や $\left[\mathrm{Ca}^{2+}\right]_{\mathrm{i}}$ の上 昇に至る応答については大きな違いはみられなかっ た。ムスカリン性レセプターに関しては， $\mathrm{M}_{3} レ$ レ 
プターの mRNA は両者で発現しているが，これに 加えてマウス膵島では $\mathrm{M}_{1}$ レセプターが, $\left.{ }^{6}\right) \beta \mathrm{TC6}$ 細 胞では $\mathrm{M}_{4}$ レセプターが発現しており，遺伝子発現 パターンに違いがみられた。現在，膵島における $\mathrm{M}_{1}$ レセプターの機能についてはまだよくわかって いない. $\mathrm{M}_{1}$ レセプターも $\mathrm{Gq}$ タンパク連結型レセ プターであるので， $\mathrm{M}_{3}$ レセプターと相互作用して その機能を調節したり，また $\beta$ 細胞以外の $\alpha$ や $\delta$ 細胞などに存在して膵島でのホルモンの分泌に関与 している可能性が考えられる． $\mathrm{M}_{4}$ レセプターにつ いては RINm5F 細胞でも発現しているので, ${ }^{33)}$ 培 養細胞に特有のレセプターである可能性が考えられ る.また, $\beta \mathrm{TC6}$ 細胞では $\mathrm{M}_{4}$ レセプターが $\left[\mathrm{Ca}^{2+}\right]_{\mathrm{i}}$ の上昇とインスリン分泌の過程に関与していること から，このレセプターの作用機構と $\mathrm{M}_{3}$ レセプター との相互作用メカニズムを調べるのに適したモデル 系あると考えられる.

一方 $\mathrm{P} 2$ レセプターについては， $\beta \mathrm{TC6}$ 細胞での $\mathrm{P}_{2} \mathrm{Y}_{1,2,4,6}$ レセプターの発現パターンは膵島と同じ であった。 また， $\left[\mathrm{Ca}^{2+}\right]_{\mathrm{i}}$ の上昇に関しても，アゴ ニストに対する反応性及びレセプター刺激によるシ グナル伝達様式に違いがみられなかった。また，グ ルコースによってインスリン分泌が促進される条件 下では，ぞちらの細胞系においても程度の違いはあ るが P2 レセプター刺激によってインスリン分泌が 抑制された。したがって，両細胞系における P2レ セプターの特性は非常に似ていることが明らかとな った。先に述べたように， $\beta \mathrm{TC6}$ 細胞はグルコース に対する反応性が非生理的であるため，グルコース 応答に関するメカニズムを調べる系としては適さな いと思われる．しかしこの細胞では，発現している レセプターの薬物に対する反応性を迅速かつ網羅的 に調べることができるので，インスリン分泌に関し て有用なモデル細胞であると考えられる。また，イ ンスリン分泌の調節に関与しているレセプター間の 相互作用を調べる研究にも適している.

6. $\beta \mathrm{TC6}$ 細胞におけるインスリンの生合成・分 泌におけるポリアミンの作用 ${ }^{34)}$

プトレシン，スペルミジン，スペルミンはすべて の細胞中に存在し, 細胞の増殖や分化などにおいて 必須の働きをするポリアミンと呼ばれる塩基性の生 理活性物質である. ${ }^{35)}$ 膵島 $\beta$ 細胞におけるポリアミ ンの働きは，ポリアミンの生合成経路を触媒するい
くつかの酵素に対する阻害剤を用いて調べられてき た。 ${ }^{36,37)}$ 特にポリアミン生合成の律速酵素である ornithine decarboxylase (ODC) の阻害剤である $\alpha$ difluoromethylornithine (DFMO) は種々の細胞, 組織や個体でのポリアミンの生理作用を明らかにす

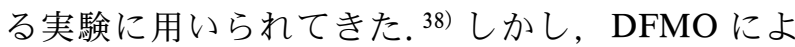
ってマウス膵島ではプトレシンとスペルミジン が, 36,39) また RINm5F 細胞ではプトレシン，スペル ミジンそしてスペルミンのすべてが細胞中で減少す ることから, ${ }^{40,41)}$ 個々のポリアミンの役割が不明瞭 であった。近年，城西大学薬学部の鮫島啓二郎教授 （現武蔵野大学薬学部客員教授）のグループによつ て，スペルミジン合成酵素とスペルミン合成酵素の 活性をそれぞれ特異的に阻害する trans-4-methylcyclohexylamine (MCHA) と $N$ - (3-aminopropyl) cyclohexylamine (APCHA) の作用が明らかにされ

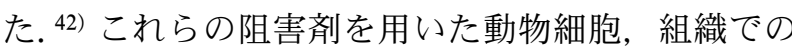
研究は数例報告されていたが, ${ }^{43-49)} \beta$ 細胞における 効果は調べられていなかった，そこでわれわれは， スペルミジン，スペルミンそれぞれの持つ機能を明 らかにする目的で, $\beta$ TC6 細胞におけるインスリン 分泌に及ぼすこれら阻害剤の影響を調べることとし た。

最初に, MCHA と APCHA が $\beta$ TC6 細胞の増殖 や細胞ポリアミン量にどのような影響を及ぼすかを 調べた結果，MCHA $(250 \mu \mathrm{M})$ 又は APCHA（100 $\mu \mathrm{M} ）$ で 3 日間処理することによって，細胞の増殖 が抑えられることがわかった。しかし，4 日間培養 しても最初に播いた細胞数は維持されていたので, どちらの阻害剤も細胞毒性は示さないと考えられ た。また，これらの阻害剂で細胞を 2-4 日間処理す ると，MCHAにより細胞中のスペルミジン量が 50 -90\%，そして APCHA によりスペルミン量が 4080\%減少することがわかつた。これらの実験結果等 から，2つの阻害剤はそれぞれ細胞中でのスペルミ ジンとスペルミン濃度を特異的に減少させることが 確かめられた。しかし一方，MCHA 処理により細 胞中のスペルミン量が，そして APCHA によりス ペルミジン量がそれぞれ増加することがわかった. また，細胞中のスペルミジンとスペルミンの総和量 は変化しなかったので，細胞中のポリアミン量を一 定に保つための補填機構が働き，その結果，それぞ れもう一方のポリアミン量が増加したと推測され 
た。また，MCHA 又は APCHA で 3 日間処理した 細胞にスペルミジン又はスペルミンを培養液中に添 加した場合，濃度依存的に細胞中のポリアミン量が 増加した。

次にわれわれは，グルコース刺激によるインスリ ン分泌におけるスペルミジン及びスペルミンの役割 を $\mathrm{MCHA} と \mathrm{APCHA}$ の存在下で $\beta \mathrm{TC6}$ 細胞を培 養して調べた。どちらの阻害剤によっても，2-4 日 間の処理で細胞のインスリン分泌量が約 $50 \%$ 減少 することが観察された。次に，この減少が細胞中で のポリアミン量の低下によるものかどうかを調べる 目的で，MCHA とスペルミジン又は APCHA とス ペルミンの共存下でそれぞれ 3 日間培養した細胞で のインスリン分泌量を調べた。その結果，MCHA とスペルミジンで同時に処理した細胞では，スペル ミジンの濃度の増加に依存してインスリン分泌の減 少が軽減した。また，スペルミジン $(100 \mu \mathrm{M})$ を 単独で添加した場合は，未処理の細胞と比較してイ ンスリン分泌が若干増加していた。これらの実験結 果から，細胞中のスペルミジン量が減少するとイン スリン分泌が低下することが明らかとなった。一方 APCHA の場合は，スペルミン添加による改善効 果はほとんどみられず，またスペルミンを単独で添 加してもインスリン分泌量の増加はみられなかった ので，APCHA によるインスリン分泌の減少はス ペルミン以外の副作用が原因であると考えられた. 以上の結果から，スペルミジンがインスリン分泌の 調節に重要であることが示唆された。

MCHA 処理によって $\beta \mathrm{TC} 6$ 細胞でのインスリン 分泌量が低下する原因として，2つの可能性が考え られた。 1 つは，細胞中のスペルミジン量が減少す ることによりインスリン遺伝子の転写（transcription）や翻訳 (translation)，そして翻訳後プロセシ ングが低下するため，2つ目は，グルコース刺激に よるインスリン分泌に必要なシグナル伝達経路のど こかに障害が生じるため，という仮説である．まず， 1 つ目の仮説を検証するために，インスリン遺伝子 の発現量を半定量的 RT-PCR 法で調べたところ,

MCHA で 3 日間処理した細胞と未処理の細胞との 間での発現量に差はみられなかった。次に, 細胞中 のインスリンペプチド量を調べたところ, MCHA 処理によって約 $50 \%$ 減少していることがわかっ た。しかし，スペルミジンと MCHA で同時に処理
した場合に MCHA の抑制効果が軽減された。ま た，スペルミジン $(100 \mu \mathrm{M})$ を単独で添加した場 合には変化がみられなかった。したがって，インス リン mRNA の翻訳若しくは翻訳後修飾の過程にス ペルミジンが重要な役割を果たしている可能性が考 えられた．2つ目の仮説については，上で述べたよ うに，グルコースによって刺激されるインスリン分 泌の過程において $\left[\mathrm{Ca}^{2+}\right]_{\mathrm{i}}$ が重要なファクターの 1 つであることから，MCHA によるスペルミジン量 の低下が及ぼす $\left[\mathrm{Ca}^{2+}\right]_{\mathrm{i}}$ への影響を調べた．Figure 5 に示した実験結果から，3 日間 MCHA で処理し た細胞では，グルコースによる $\left[\mathrm{Ca}^{2+}\right]_{\mathrm{i}}$ の持続的 な上昇が若干抑制され，またこの抑制がスペルミジ ンの同時添加によりある程度軽減することがわかつ た。一方 MCHA の影響は, 高濃度の $\mathrm{KCl}(40$ $\mathrm{mm})$ ，カルバコール，ニコチン等によるインスリ ン分泌の刺激の際に起こる $\left[\mathrm{Ca}^{2+}\right]_{\mathrm{i}}$ の上昇につい てはみられなかった。したがって，スペルミジンは グルコースによる $\left[\mathrm{Ca}^{2+}\right]_{\mathrm{i}}$ の上昇に選択的に関与 するなんらかの因子に影響を及ぼしている可能性が 考えられる. しかし，現時点ではその詳細について は不明である。

以上の実験から，インスリン分泌の調節にスペル ミジンが重要であることが明らかとなった。今後 は，このスペルミジンの作用機序について調へ，膵 島あるいは他の細胞株，また生体を用いてその生理 的意義を明らかにしていきたいと考えている.

\section{7. 脺蔵がん細胞のグルカゴン産生細胞への分化} 誘導におけるアンチザイムの重要性 ${ }^{50)}$

糖尿病の新たな治療法として, 膵島の再生医療が 注目されこの分野での研究が近年盛んに行われてい るが，膵島細胞の増殖と分化調節機構についてはま だ不明な点が多い，膵島 $\alpha$ 細胞は，血糖値を上昇 させる主要なホルモンの 1 つであるグルカゴン アミノ酸残基)を生合成・分泌する，グルカゴンは, glucagon-like peptide 1/2（GLP-1/2）のアミノ酸配 列を含む前駆体タンパクであるプログルカゴンから prohormone convertase 2（PC2）によりプロセシン グを受けて $\alpha$ 細胞で生合成，分泌される. ${ }^{51)}$ また, 消化管から分泌される GLP-1 は膵島の分化や成熟 に重要な役割を果たしているだけではなく，インス リン分泌や $\beta$ 細胞の増殖を促進する作用等を持つ ていることから，糖尿病治療薬の有望な候補物質と 


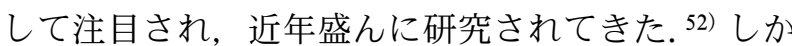
し, 膵島 $\alpha$ 細胞の増殖及び機能的分化の調節機構 はまだ解明されていない点が多い。近年，ヒト膵が ん PANC-1 細胞をトリプシンで短時間処理した後 に無血清培地で培養することにより，がん細胞が膵 ホルモンを産生する膵島様細胞に変化することが報 告されていた. ${ }^{53,54)}$ われわれは同様の現象を他のい くつかの膵がん細胞株でも見い出し，膵島での細胞 分化の調節機構を探るためのモデル系として研究を 行った.

われわれの実験から，ヒト膵がん細胞株である AsPC-1 細胞は，短時間のトリプシン処理後 6 日間 無血清培地での培養により膵島様の形態の細胞へと 分化し，また分化した細胞が $\alpha$ 細胞に特異的なグ ルカゴンを産生することが明らかになった［Fig. 6 (A)]。グルカゴン産生については，RT-PCR 法に よるグルカゴン遺伝子の発現の有無と, 抗グルカゴ ン抗体を用いたフローサイトメトリー法及び蛍光免 疫染色法で確認した。また同様の培養手法と条件に よって，PANC-1 など 4 種類のヒト膵がん細胞株 をインスリンとグルカゴンの両方のホルモンを産生 する細胞へと分化誘導することができた [Fig. 6 (B) ]。AsPC-1 細胞が膵島様細胞に分化する過程に

\section{A Differentiation of pancreatic tumor cells}

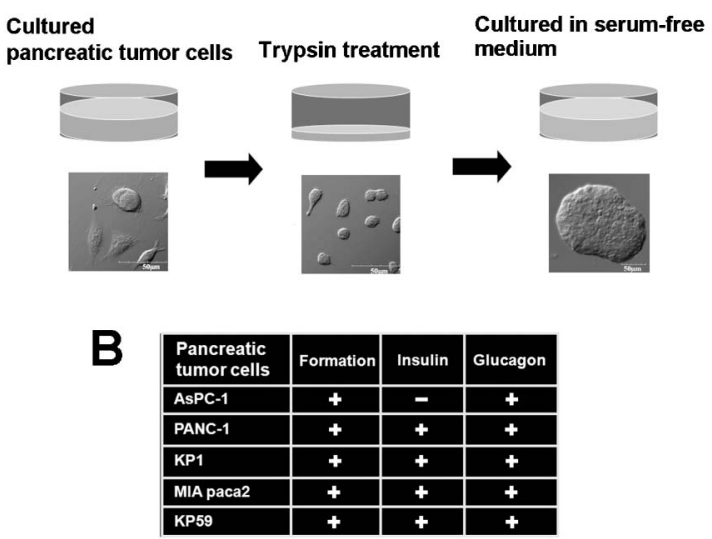

Fig. 6. Induction of Differentiation of Human Pancreatic Tumor Cells into Endocrine-like, Hormone-producing Cells

(A) Five human pancreatic tumor cell lines, AsPC-1, PANC-1, KP1, MIA paca2 and KP59, grown in the presence of $10 \%$ fetal bovine serum (FBS) were briefly treated with trypsin and then cultured in chemically defined Dulbecco's modified Eagle's medium (DMEM)/F10 medium $(17.5 \mathrm{~mm}$ glucose, $1 \%$ bovine serum albumin) in the absence of FBS for 6 days. The cultured cells became differentiated and formed islet-like aggregates as shown. Scale bars: $50 \mu \mathrm{m}$. (B) The list of human pancreatic tumor cells and their differentiation property to form islet-like aggregates and synthesize pancreatic hormones, insulin and glucagon.
おいて，グルカゴン遺伝子の発現に関与する Pax6 やPDX-1 などの転写因子や PC2，そして膵島様構 造への形態変化及びその形成に必要な接着因子であ る E-カドヘリンなどの mRNA の発現が増加するこ とも認められた。また分化誘導した AsPC-1 細胞 は，通常の膵島 $\alpha$ 細胞と同様に，グルカゴンの産 生量が低濃度グルコース存在下においては増加し, 高濃度グルコースでは減少した。また膵島 $\alpha$ 細胞 において，グルカゴン産生はインスリンの作用によ り低下するが, ${ }^{55,56)}$ 分化した AsPC-1 細胞における グルカゴンの産生もインスリンの作用により減少し た。これらの結果より，分化誘導された AsPC-1 細 胞は生体内の膵島 $\alpha$ 細胞に近い特性を有している ことが示唆された。

次に，この細胞系を用いてグルカゴン産生細胞へ の分化誘導のメカニズムを明らかにするため, 細胞 内の制御分子の探索を行った，その結果，プロテア ソームを介して ODC の分解を引き起こし，細胞内 ポリアミン量を負に調節する機能を持つタンパク質 であるアンチザイム $1^{57,58)}$ が分化誘導の過程で増加 し，さらにその局在が核から細胞質へと変わること を見い出した。次に AsPC-1 細胞の分化におけるア ンチザイム 1 の必要性を調べるために, small interfering RNA（siRNA）を用いてアンチザイム 1 の発 現を低下させ，分化誘導への影響を検討した。 その 結果，アンチザイム 1 の発現が減少した細胞では, 分化誘導に伴う形態変化が不完全でグルカゴンは産 生されず，またPax6やE-カドヘリンの発現も同時 に低下していた。一方，アンチザイム 1 を過剩発現 させた場合，グルカゴン産生が促進されることがわ かった。また， siRNA を用いた同様の実験を他の インスリンを産生する PANC-1 等のがん細胞株を 用いて行った結果，アンチザイム 1 の発現低下はイ ンスリン産生に影響を及ぼさなかった。したがっ て，アンチザイム 1 は $\beta$ 細胞の分化誘導には必要 でないことが示唆された。

アンチザイム 1 が細胞中のポリアミン量を調節す る機能を持つことから，分化誘導に伴う細胞中のポ リアミン量の変化を調べた。その結果，分化誘導の 過程でプトレシン量は減少するが，スペルミジンと スペルミン量は変化しないことがわかった，次に， 細胞中のプトレシン量の低下と AsPC-1 細胞の分化 との関係を調べるために，細胞外からプトレシンを 
添加し細胞中の量を増加させた場合の細胞分化への 影響を検討したところ，グルカゴン産生等の分化発 現は影響を受けなかった。これらの実験結果から， アンチザイム 1 によるプトレシン量の減少は AsPC-1 細胞の分化に直接影響を及ぼしていないこ とが示唆された。以上の結果から，ヒト膵がん細胞 のグルカゴン産生細胞への分化誘導にはアンチザイ ム 1 が必須であり，またその働きはプトレシン産生 とは異なった標的機構を介して発現することが示唆 された.

アンチザイムの生体における膵島分化での役割は 明らかにされていないが，われわれは生体内の膵島 におけるアンチザイムの発現の有無を調べ，アンチ ザイムが膵島 $\alpha$ 及び $\beta$ 細胞に発現していることを 見い出している. 現在, このタンパク質が生体の膵 島 $\alpha$ 細胞の機能発現において果たしている役割を 明らかにし，さらにその作用機序の解明を行うため の研究を計画中である.

\section{8. おわりに}

以上に述べた研究を通じてわれわれは，膵臓内分 泌細胞の機能の調節に係わる新規の分子を見い出 し，それらの働きの一端を解明することができた。

これら分子が新規の糖尿病治療薬の開発のための リード化合物となり得るかどうかについては，今後 $\mathrm{P}^{2} \mathrm{Y}_{6}$ レセプター，スペルミジンやアンチザイム 1 などについて，初代培養膵島やマウス等の動物を用 いて, 生体内での各分子の機能を解明する研究を行 う必要がある。またわれわれは，複数のヒト膵がん 細胞株を一定の培養条件下でホルモン産生細胞へと 分化誘導できることを見い出した．今後はこの研究 をさらに発展させて,「分化誘導による膵がん細胞 の正常化によるがんの治療法」の開発に役立つ知見 を得るように努力していきたい。

\section{謝辞以上の研究を遂行するにあたつて, NIH} の故 John W. Daly 博士, Kenneth A. Jacobson 博 士, Jürgen Wess 博士, Georgetown University の Kenneth J. Kellar 博士, Yingxian Xiao 博士をはじ め, 武蔵野大学薬学部の鮫島啓二郎客員教授，村上 安子客員教授（現慈恵医科大学客員教授），湧永製 薬の水野郁子研究員及び武蔵野大学薬学部遺伝子学 研究室の学部生の方々に協力して頂いたことに心よ り感謝を申し上げたい。また, 本研究は, 科学研究
費補助金及び文部科学省の「ハイテクリサーチ整備 事業（MEXT-HAITEKU）」からの支援金により遂 行されたものであり，ここに厚く御礼申し上げたい．

\section{REFERENCES}

1) Ohtani M., Oka T., Badyuk M., Xiao Y., Kellar K. J., Daly J. W., Mol. Pharmacol., 69, 899-907 (2006).

2) Gilon P., Henquin J. C., Endocr. Rev., 22, 565-604 (2001).

3) Henquin J. C., Nenquin M., FEBS Lett., 236, 89-92 (1988).

4) Karlson S., Ahrén B., J. Auton. Pharmacol., 13, 439-446 (1993).

5) Boschero A. C., Szpak-Glasman M., Carneiro E. M., Bordin S., Paul I., Rojas E., Atwater I., Am. J. Physiol., 268, 336-342 (1995).

6) Duttaroy A., Zimliki C. L., Gautam D., Cui Y., Mears D., Wess J., Diabetes, 53, 17141720 (2004).

7) Gautam D., Han S. J., Hamdan F. F., Jeon J., Li B., Li J. H., Cui Y., Mears D., Lu H., Deng C., Heard T., Wess J., Cell Metab., 3, 449-461 (2006).

8) Kakei M., Dezaki K., Yada T., Nippon Yakurigaku Zasshi, 124, 345-352 (2004).

9) Daly J. W., Cell Mol. Neurobiol., 25, 513-552 (2005).

10) Jensen A. A., Frølund B., Liljefors T., Krogsgaard-Larsen P., J. Med. Chem., 48, 47054745 (2005).

11) Parker M. J., Beck A., Luetje C. W., Mol. Pharmacol., 54, 1132-1139 (1998).

12) Xiao Y., Kellar K. J., J. Pharmacol. Exp. Ther., 310, 98-107 (2004).

13) Ohtani M., Daly J. W., Oka T., Eur. J. Pharmacol., 604, 150-157 (2009).

14) Yoshikawa H., Hellström-Lindahl E., Grill V., Metabolism, 54, 247-254 (2005).

15) Poitout V., Stout L. E., Armstrong M. B., Walseth T. F., Sorenson R. L., Robertson R. P., Diabetes, 44, 306-313 (1995).

16) Ohtani M., Suzuki J., Jacobson K. A., Oka T., Purinergic Signal., 4, 365-375 (2008).

17) Burnstock G., Br. J. Pharmacol., 147, 172181 (2006).

18） Lazarowski E. R., Boucher R. C., Harden T. K., Mol. Pharmacol., 64, 785-795 (2003). 
19) Burnstock G., Knight G. E., Int. Rev. Cytol., 240, 31-304 (2004).

20) Relavic V., Burnstock G., Pharmacol. Rev., 50, 413-492 (1998).

21) Obermüller S., Lindqvist A., Karanauskaite J., Galvanovskis J., Rorsman P., Barg S., $J$. Cell Sci., 118, 4271-4282 (2005).

22) Franke H., Illes P., Pharmacol. Ther., 109, 297-324 (2006) .

23) Jacobson K. A., Jarvis M. F., Williams M., $J$. Med. Chem., 45, 4057-4093 (2002).

24) Blachier F., Malaisse W. J., Biochim. Biophys. Acta, 970, 222-229 (1988).

25) Petit P., Hillarie-Buys D., Manteghetti M., Debrus S., Chapal J., Loubatières-Mariani M. M., Br. J. Pharmacol., 125, 1368-1374 (1998).

26) Chevassus H., Roig A., Belloc C., Lajoix A. D., Broca C., Manteghetti M., Petit P., Naunyn-Schmiedeberg's Arch. Pharmacol., 366, 464-469 (2002).

27) Farret A., Vignaud M., Dietz S., Vignon J., Petit P., Gross R., Diabetes, 53, S63-S66 (2004).

28) Fernandez-Alvarez J., Hillarie-Buys D., Loubatières-Miriani M. M., Gomis R., Petit P., Pancreas, 22, 69-71 (2001).

29) Poulsen C. R., Bokvist K., Olsen H. L., Нøy M., Capito K., Gilon P., Diabetes, 48, 21712181 (1999).

30) Léon C., Freund M., Latchoumanin O., Farret A., Petit P., Cazenave J.-P., Gachet C., Purinergic Signal., 1, 145-151 (2005).

31) Parandeh F., Abaraviciene S. M., Amisten S., Erlinge D., Salehi A., Biochem. Biophys. Res. Commun., 370, 499-503 (2008).

32) Buchanan C. M., Phillips A. R., Cooper G. J., Biochem. J., 360, 431-439 (2001) .

33) Tang S. H., Sharp G. W., Diabetes, 46, 14191423 (1997).

34) Ohtani M., Mizuno I., Kojima Y., Ishikawa Y., Sodeno M., Asakura Y., Samejima K., Oka T., Cell Struct. Funct., 34, 105-113 (2009).

35) Thomas T., Thomas T. J., J. Cell. Mol. Med., 7, 113-126 (2003).

36) Welsh N., Sjöholm A., Biochem. J., 252, 701707 (1988).

37) Sjöholm A., Am. J. Physiol. Cell Physiol.,
270, C1105-C1110 (1996).

38) Marton L. J., Pegg A. E., Annu. Rev. Pharm. Toxicol., 35, 55-91 (1995).

39) Welsh N., Biochem. J., 271, 393-397 (1990).

40) Sjöholm A., Welsh N., Hoftiezer V., Bankston P. W., Hellerström C., Biochem. J., 277, 533-540 (1991).

41) Sjöholm A., Arkhammar P., Welsh N., Bokvist K., Rorsman P., Hallberg A., Nilsson T., Welsh M., Berggren P. O., J. Clin. Invest., 92, 1910-1917 (1993).

42) Shirahata A., Morohoshi T., Fukai M., Akatsu S., Samejima K., Biochem. Pharmacol., 41, 205-212 (1991).

43) Shirahata A., Takahashi N., Beppu T., Hosoda H., Samejima K., Biochem. Pharmacol., 45, 1897-1903 (1993).

44) Chu P. J., Shirahata A., Samejima K., Saito H., Abe K., Eur. J. Pharmacol., 256, 155-160 (1994).

45) Beppu T., Shirahata A., Takahashi N., Hosoda H., Samejima K., J. Biochem., 117, 339345 (1995).

46) Chu P. J., Shirahata A., Samejima K., Saito H., Abe K., Jpn. J. Pharmacol., 69, 311-315 (1995)

47) Haider N., Eschbach M. L., Dias Sde S., Gilberger T. W., Walter R. D., Lüersen K., Mol. Biochem. Parasitol., 142, 224-236 (2005).

48) Nishimura K., Murozumi K., Shirahata A., Park M. H., Kashiwagi K., Igarashi K., Biochem. J., 385, 779-785 (2005) .

49) Kobayashi M., Takao K., Shiota Y., Sugita Y., Takahashi M., Nakae D., Samejima K., Biol. Pharm. Bull., 29, 863-867 (2006) .

50) Suzuki J., Murakami Y., Samejima K., Kohda K., Ohtani M., Oka T., Endocr. Relat. Cancer, 16, 649-659 (2009).

51) Vincent M., Guz Y., Rozenberg M., Webb G., Furuta M., Steiner D., Teitelman G., Endocrinology, 144, 4061-4069 (2003).

52) Winzell M. S., Ahrén B., Pharmacol. Ther., 116, 437-448 (2007).

53) Hardikar A. A., Marcus-Samuels B., GerasRaaka E., Raaka B. M., Gershengorn M. C., Proc. Natl. Acad. Sci. USA., 100, 7117-7122 (2003).

54) Gershengorn M. C., Hardikar A. A., Wei C., Geras-Raaka E., Marcus-Samuels B., Raaka 
B. M., Science, 306, 2261-2264 (2004).

55) Maruyama H., Hisatomi A., Orci L., Grodsky G., Unger R., J. Clin. Invest., 74, 2296-2299 (1984).

56) Philippe J., J. Clin. Invest., 84, 672-677
(1989).

57) Hayashi S., Murakami Y., Matsufuji S., Trends Biochem. Sci., 21, 27-30 (1996).

58) Coffino P., Nat. Rev. Mol. Cell Biol., 2, 188194 (2001). 